\title{
IPM Managing water for weed control in rice
}

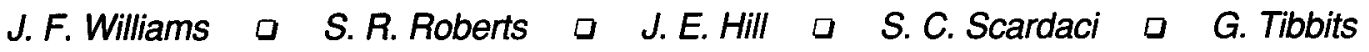

\begin{abstract}
A strategy of slightly deeper water, no draining, and lower grass herbicide rates can help rice growers maintain weed control and sustain high yields while lowering the economic and runoff costs of herbicides.
\end{abstract}

Over the past decade, a rice cultural system has developed to maximize the performance of modern short-stature cultivars. The system includes precisionleveling, very shallow flooding, temporary draining, and high fertilization rates. Unfortunately, thiscultural systemalso promotes weeds thatmay require high rates and multiple applications of herbicides for control, and that increases the economic, social, and environmental costs of growing rice. Growers are spending more for weed control, and in 1981 objectionable levels of rice herbicide residues were discovered in public waterways. Rice growers must now follow increasingly strict regulations to keep residues within allowable limits. They rely mainly on tailwater return systems and ponding on fallow land, but the industry needs additional tools to control rising production costs and to keep up with residue "performance goals" that get lower every year.

From 1985 through 1987, we examined the management of water in California rice production, looking for ways to reduce herbicide use while maintaining crop performance. Specific research objectives included determining rice and weed response to water depth and drainage; estimating the degree of control provided by water alone; and evaluating cultivar responses to different water depths. Our results have economic and environmental value for conventional and alternative rice producers.

With funding from the Statewide IPM Project, we established a large-scale, multiuse water management facility in a commercial rice field in Sutter County, California. The 34-acre site included 36 individually irrigated and drained basins arranged with 18 basins on each side of a central irrigation canal. On one side of the canal, the basins received noherbicide treatment; on theother side, basins received annual aerial applications of $5 \mathrm{lb} / \mathrm{ac}$ molinate (Ordram 10G) for watergrass control and $1 \mathrm{lb} / \mathrm{ac}$ bentazon (Basagran) plus oil for broadleaf and sedge control. Each set of 18 basins comprised three replicates of six water management regimes that represented a range of those typically used in California rice production; the same randomization was used every year:

1. shallow-continuous 2 -inch water depth

2. moderate-continuous5-inch waterdepth

3. deep - continuous 8-inch water depth

4. early drain - drain 2 days after planting (DAP) for 4 to 5 days, and reflood to a 5 inch continuous water depth

5. late drain - flood to 5 inches until about 20 DAP, drain until about 30 DAP, and reflood and hold at 5 inches continuous water depth

6. lowered - flood to 8 inches for $21 \mathrm{DAP}$, lower to 5 inches, and hold

Treatments 1 through 3 (shallow, moderate, and deep) represent the full range of water depths used in California, and were established before rice emergence so the plants would have to grow through theentiredepth of water. Early drain (treatment 4) provides an aerated environment during stand establishment, favoring rootgrowthover shoot growth, speeding root penetration into the soil. Late drain (treatment 5) simulates a practice followed when rice fields are stressed: draining helps relieve the stress and promotes recovery. Lowered (treatment 6) was a commonly used method before the advent of herbicides, and takes advantage of the differing ability of rice and weeds to emerge through deep water. By lowering the water at a strategic time, the grower gives the rice an advantage over the weeds. Each treatment was held for approximately 75 days after planting, and then all water levels were raised to about 8 inches for the remainder of the water season.

Pre-soaked seed (cultivar M-201) was sown by air at $150 \mathrm{lb} / \mathrm{ac}$. We rated weed control visually on a 1-to-10 scale, where 1 equals no control and 10 equals complete control. We also collected data on rice plant population, days to $50 \%$ heading, height, lodging, grain moisture, grain yield, water temperature, rice growth, and cultivar performance.

\section{Weed control}

The initial weed composition was a uniformly distributed stand of common rice weeds (table 1): barnyardgrass, smallflower umbrellaplant, redstem, and ducksalad were most common and uniformly present. Watergrass, not present in the native weed population, was sown at 10 seeds $/ \mathrm{ft}^{2}$ in 1985 in 10-x-80-foot plotsineach basin. Roughseed bulrush was not uniformly distributed at the start, but it spread throughout the trial site during the course of the experiment. Weed growthin response to water treatments is discussed in the sidebar and corresponds reasonably well with the control ratings discussed here.

Grass control ratings in the $10-x-80$-foot plots (table 1) improved with increasing water depths. The best weed control without herbicides was in the deepest water, whileshallow water and early drainage gave poor control. Molinate gave adequate control of grasses in all water treatments except shallow and late drain. Cold weather lowered the herbicide's activity and resulted in poorer control in 1985, reducing the 3-year mean for that treatment. Barnyardgrass control in late drain was also lower in 1987. Under optimal conditions for herbicidal activity, molinate provided excellent control in all water treatments.

Estimates of the two Echinochloa species' populations at the end of each season revealed that barnyardgrass responded more than watergrass to increasing water depths: more of the surviving grass was watergrass in deep water ( $45 \%)$ than in shallow water (14.9\%). The absoluteamount of both species was less in deeper water, but the relative increase of watergrass in deep water suggests selective pressure in favor of watergrass, which growers generally consider harder to control.

Roughseed bulrush had spread throughout the untreated section of the site by the beginning of the second year. This weed was relatively unresponsive to water depth (table 1), and was the dominant weed species in nonchemical deep treatments that suppressed grasses. Grass weeds dominated roughseed bulrush in shallow water, but where grass weeds are absent, roughseed bulrush can be a serious rice competitor in shallow water if not controlled. Bentazon 
controlled it very well each year in every water treatment.

Smallflower umbrellaplant (table 1) responded well to water depth, with the poorest control achieved in the shallow and late drain treatments without herbicides. Bentazon also provided poor control in shallow and drained plots, so these treatments may stimulate the development of smallflower umbrellaplant and reduce the efficacy of herbicides.

Redstem ratings were only slightly lower (table 1) in deeper water than in shallow and drained treatments. Bentazon gave nearly complete control in all water treatments. Water depth is not critical in managing this weed, although it may be some help.

Ducksalad is a common rice weed that may have dense growth in open water areas, but because of its short stature it competes poorly in normal-density ricestands. Though ducksalad responded slightly to increasing water depths the first year, domination by more competitive weeds in later years rendered multiyear ratings less meaningful (table 1). Overall, ducksalad did not show any strong response either to water depth or to drainage. Bentazon provided only partial control of ducksalad in all water treatments, and there was no interaction of water and herbicide.

An increased water depth suppresses some rice weeds more than others. As measured by visual ratings, barnyardgrass, watergrass, and smallflower umbrellaplant are strongly affected, redstem species are slightly to moderately affected, and ducksalad and roughseed bulrush are slightly or not at all affected by an 8-inch continuous water depth treatment. Other common rice weeds noted in the study were sprangletop (strongly affected) and California arrowhead (slightly or not at all affected).

Increasing water depths also increased the herbicide's efficacy on watergrass and smallflower umbrellaplant. Conversely, shallow water and drainage increased the severity of weed infestations and reduced herbicidal efficacy. Bentazon activity against roughseed bulrush, redstem, and ducksalad was not influenced by water treatments.

\section{Rice growth and performance}

The combined potential for stand loss, slow emergence, and weak rice plants make rice growers dislike deep-water culture. In standing water, growth is always stressful during seedling establishment, and deep water can jeopardize thecrop. It is important, then, to determine a safe limit for water

\section{Water management effects on rice weed growth}

Weed growth measurements taken in 1986 from the no-herbicide side of the study described in the companion articlesupport one of the project's main findings - that water management can be an important tool for weed control. Early in the season, we collected 20 weeds every week from each water treatment and measured them for height and top biomass. Late-season measurements wereless frequent. Biomass is reported in order to show the effects of different water regimes on weed growth.

In the early season, biomass of all weed species except roughseed bulrush decreased significantly as the depth of the water increased (fig. 1). The trend of decreasing biomass with increasing water depth was generally consistent for all weed species and sampling dates. Even though we measured some large differences in biomass, the high degree of variability made it hard to show significance in some cases.

Deepwater effectively suppressed weed growth early in the season, while shallow water enhanced it. In deep water, weeds were generally smaller, and in some cases they appeared weak. Those in shallow water were larger and appeared to be vigorous and competitive.

Deep water suppressed the growth of someweeds more than others. Smallflower umbrellaplant and watergrass were affected the most by deep water, while roughseed bulrush was affected the least. In deep water, smallflower umbrellaplant biomass was 72 and $90 \%$ less than in shallow water $(\mathrm{P}=.05)$ at 34 and $41 \mathrm{DAP}$, respectively, and watergrass biomass was reduced by more than $80 \%(\mathrm{P}=.05)$ at 27 DAP. Even though roughseed bulrush tended to have less biomass in deeper water, the differences were not significant.

Redstem and ducksalad were intermediate in their reaction to water depth. Redstem biomass was 46 and $50 \%$ less in deep water than in shallow $(\mathrm{P}=.05)$ at 27 and55DAP, respectively, whileducksalad biomass was $34 \%$ less ( $\mathrm{P}=.05 ; 34 \mathrm{DAP})$.

The presence of a mixture of two watergrass species, Echinochloa oryzoides and E. crus-galli, each with a different growth habit and a different response to water depth, confounded the watergrass growth measurements.

Late-season weed biomass decreased for most weed species as water depth decreased. This trend is the opposite of the early season pattern, and probably results from the greater density and height of watergrass that grew in shallow water.

Late drainage (20 to 30 DAP) enhanced the growth of smallflower umbrellaplant, watergrass, and redstem, as compared to the comparable continuously flooded treatment. These species had significantly more biomass at 27 DAP. The differences in growth helpexplain the reduced control of smallflower umbrellaplant and watergrass in the late drain treatment.

The effects of water depth and drainage on the growth of smallflower umbrellaplant, watergrass, and to a lesser extent redstem, explain the differences in weed control that we observed. The impact of these water management practices on other weed species is apparently transitory or insufficient to materially effect weed control.

Sidebar authors are S. C. Scardaci, S. R. Roberts, J. F. Williams, and J. E. Hill.

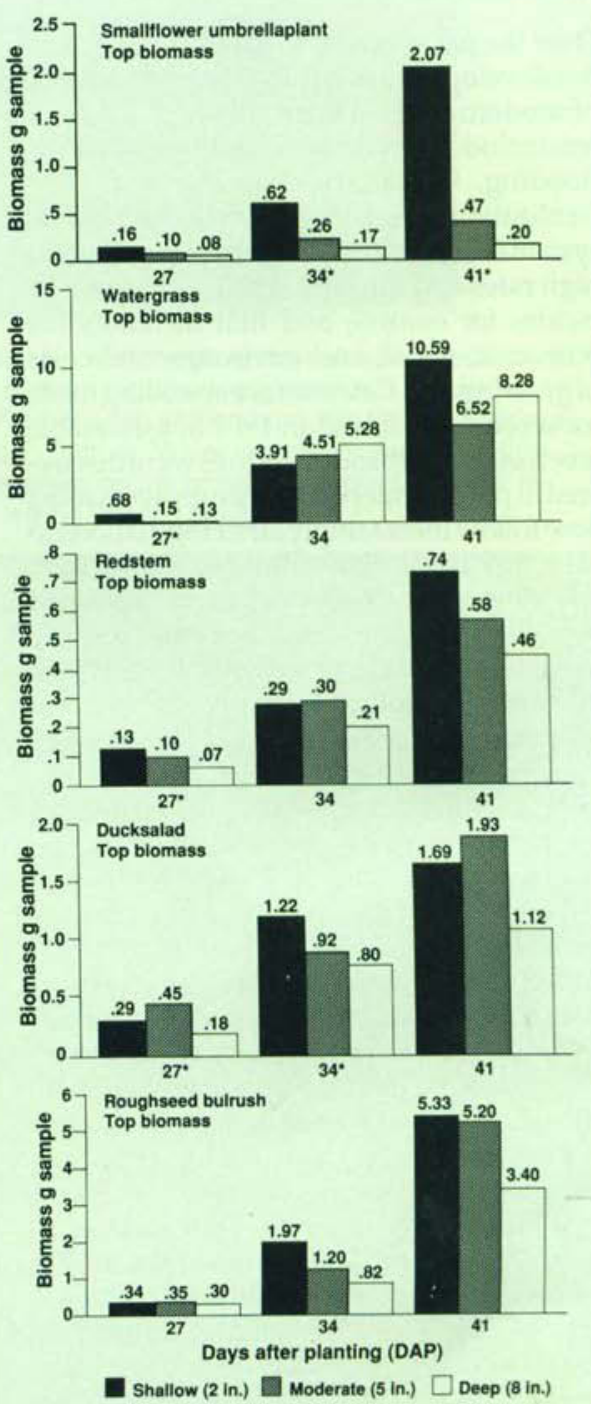

Fig. 1. Early season water depths have varying effects on different weeds (* denotes significant difference $[P=.05]$ among depths). 
TABLE 1. Control ratings for major weeds*, 1985-1987 combined analysis

\begin{tabular}{|c|c|c|c|c|c|}
\hline \multirow[b]{2}{*}{$\begin{array}{l}\text { Water } \\
\text { treatment }\end{array}$} & \multicolumn{5}{|c|}{ Weed species } \\
\hline & $\begin{array}{c}\text { ECHCG \& } \\
\text { ECHOR }\end{array}$ & SCMPU & CYPDI & АMMCO & HETLI \\
\hline \multicolumn{6}{|c|}{ Without herbicides } \\
\hline $\begin{array}{l}\text { Shallow } \\
\text { Moderate } \\
\text { Deep } \\
\text { Early drain } \\
\text { Late drain } \\
\text { Lowered } \\
\text { Mean }\end{array}$ & $\begin{array}{l}1.6 \mathrm{~g} \\
4.9 \mathrm{e} \\
7.7 \mathrm{c} \\
3.5 \mathrm{f} \\
5.3 \mathrm{~d} \\
6.1 \mathrm{~d} \\
4.8 \mathrm{~b}\end{array}$ & $\begin{array}{l}5.8 \mathrm{bcd} \\
5.8 \mathrm{bcd} \\
6.4 \mathrm{bc} \\
6.8 \mathrm{~b} \\
5.4 \mathrm{~cd} \\
4.7 \mathrm{~d} \\
5.9 \mathrm{~b}\end{array}$ & $\begin{array}{l}4.0 \mathrm{~d} \\
7.7 \mathrm{bc} \\
9.0 \mathrm{ab} \\
7.6 \mathrm{c} \\
4.2 \mathrm{~d} \\
7.8 \mathrm{bc} \\
6.7 \mathrm{~b}\end{array}$ & $\begin{array}{l}4.2 \mathrm{c} \\
4.4 \mathrm{c} \\
6.9 \mathrm{~b} \\
5.2 \mathrm{c} \\
4.7 \mathrm{c} \\
5.2 \mathrm{c} \\
5.1 \mathrm{~b}\end{array}$ & $\begin{array}{l}6.2 \\
5.1 \\
6.4 \\
5.9 \\
5.9 \\
4.9 \\
5.7\end{array}$ \\
\hline \multicolumn{6}{|l|}{ With herbicides } \\
\hline $\begin{array}{l}\text { Shallow } \\
\text { Moderate } \\
\text { Deep } \\
\text { Early drain } \\
\text { Late drain } \\
\text { Lowered } \\
\text { Mean }\end{array}$ & $\begin{array}{l}8.3 \mathrm{bc} \\
9.0 \mathrm{ab} \\
9.7 \mathrm{a} \\
8.5 \mathrm{bc} \\
7.8 \mathrm{c} \\
9.0 \mathrm{ab} \\
8.7 \mathrm{a}\end{array}$ & $\begin{array}{r}10.0 \mathrm{a} \\
9.8 \mathrm{a} \\
10.0 \mathrm{a} \\
10.0 \mathrm{a} \\
9.6 \mathrm{a} \\
9.8 \mathrm{a} \\
9.9 \mathrm{a}\end{array}$ & $\begin{array}{l}7.9 \mathrm{c} \\
8.9 \mathrm{abc} \\
9.8 \mathrm{a} \\
8.8 \mathrm{abc} \\
7.7 \mathrm{bc} \\
9.0 \mathrm{ab} \\
8.9 \mathrm{a}\end{array}$ & $\begin{array}{r}10.0 \mathrm{a} \\
9.8 \mathrm{a} \\
9.4 \mathrm{a} \\
10.0 \mathrm{a} \\
10.0 \mathrm{a} \\
9.8 \mathrm{a} \\
9.8 \mathrm{a}\end{array}$ & $\begin{array}{l}7.8 \\
8.4 \\
8.5 \\
7.8 \\
7.6 \\
8.3 \\
8.1 \mathrm{a}\end{array}$ \\
\hline \multicolumn{6}{|l|}{ LSD, $5 \%$} \\
\hline Herbicide & 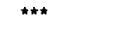 & $\star \star \star *$ & 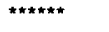 & $\star \star \star \star *$ & \\
\hline $\begin{array}{l}\text { Water } \\
\text { Herbicide }\end{array}$ & $m * *$ & ns & ${ }^{* * *}$ ns & ns & \\
\hline $\begin{array}{l}\text { and water } \\
\mathrm{CV}, \%\end{array}$ & $\begin{array}{c}1.04 \\
16.2\end{array}$ & $\begin{array}{r}1.2 \\
16.2\end{array}$ & $\begin{array}{r}1.4 \\
18.9\end{array}$ & $\begin{array}{r}1.2 \\
16.4\end{array}$ & $\begin{array}{l}\text { ns } \\
19.3\end{array}$ \\
\hline
\end{tabular}

${ }^{\star} E C H C G=$ Echinochloa crus-galli (barnyardgrass); ECHOR = E. oryzoides (watergrass); SCPMU = Scirpus mucronatus (roughseed bulrush); CYPDI = Cyperus difformis (smallflower umberllaplant); AMMCO = Ammania spp.

(redstem); HETLI = Heteranthera limosa (DUCKSALAD).

Means for treatments are not significantly different at $P=5 \%$ if followed by the same letter.

depth that will maximize the suppression of weeds without unacceptable risks. Several of our measurements demonstrated the effects of water management on rice growth. Plant population at 28 DAP (table 2) was not significantly affected by water depth, although there was a small but significant reduction in herbicide-treated plots. Even though populations varied greatly from year to year, stands were adequate for maximum crop performance each year in every treatment.

Rice growers see rapid development as a sign of successful stand establishment, and equate slow emergence and development with poor performance. Time to $50 \%$ emergence was estimated visually at 9,14 , and 19 to 21 DAP for shallow, moderate, and deep treatments, respectively. The overall appearance of the crop in shallow water during stand establishment was that of a rapidly covering stand of vigorous plants; in deep water, stands looked thin and plants spindly, with leaves lying on the water and much water surface exposed. These visual differences quickly disappeared as the crop developed. Leaves lying on the water surface have been associated with leaf miner damage, although we did not observe this problem in our study.

Measurements of leaf stage, number of tillers, and biomass accumulation over time (fig. 1) show that rice developed morequickly in shallow water than in deeperwater. These differences were greatest early in the season, and diminished with time, eventually becoming similar at all water depths.
TABLE 2. Effect of water management, with and without herbicides, on agronomic performance of $\mathrm{M}-201$ rice

\begin{tabular}{|c|c|c|c|c|c|c|}
\hline $\begin{array}{l}\text { Water } \\
\text { treatment }\end{array}$ & $\begin{array}{l}\text { Plant } \\
\text { popu- } \\
\text { lation }\end{array}$ & $\begin{array}{c}\text { Days to } \\
50 \% \\
\text { heading }\end{array}$ & $\begin{array}{c}\text { Plant } \\
\text { height }\end{array}$ & $\begin{array}{c}\text { Lodg- } \\
\text { ing }\end{array}$ & $\begin{array}{c}\text { Harvest } \\
\text { moist. } \\
\text { moisture }\end{array}$ & $\begin{array}{c}\text { Grain } \\
\text { yield } \\
(14 \% \text { molst. })\end{array}$ \\
\hline Without herbic & $\begin{array}{l}\# / s q . f t . \\
\text { des }\end{array}$ & & $\mathrm{cm}$ & $\%$ & $\%$ & $l b / a c$ \\
\hline $\begin{array}{l}\text { Shallow } \\
\text { Moderate } \\
\text { Deep } \\
\text { Early drain } \\
\text { Late drain } \\
\text { Lowered } \\
\text { Mean }\end{array}$ & $\begin{array}{l}29.2 \\
28.6 \\
27.6 \\
32.7 \\
29.4 \\
31.0 \\
29.7 \mathrm{a}\end{array}$ & $\begin{array}{l}103 \mathrm{a} \\
97 \mathrm{bcd} \\
94 \mathrm{f} \\
98 \mathrm{bc} \\
98 \mathrm{bc} \\
96 \mathrm{~cd} \\
97.6 \mathrm{a}\end{array}$ & $\begin{array}{l}70 \mathrm{c} \\
80 \mathrm{ab} \\
80 \mathrm{ab} \\
81 \mathrm{a} \\
80 \mathrm{a} \\
80 \mathrm{a} \\
78.4\end{array}$ & $\begin{array}{r}14.7 \\
5.6 \\
1.0 \\
9.6 \\
1.9 \\
6.0 \\
6.8 \mathrm{a}\end{array}$ & $\begin{array}{l}28.1 \mathrm{a} \\
26.1 \mathrm{~b} \\
20.9 \mathrm{~cd} \\
25.7 \mathrm{~b} \\
24.2 \mathrm{~b} \\
24.3 \mathrm{~b} \\
24.9 \mathrm{a}\end{array}$ & $\begin{array}{l}2,079 \mathrm{e} \\
4,502 \mathrm{~cd} \\
6,366 \mathrm{~b} \\
4,501 \mathrm{~cd} \\
3,958 \mathrm{~d} \\
5,216 \mathrm{bc} \\
4,437 \mathrm{~b}\end{array}$ \\
\hline $\begin{array}{l}\text { With herbicide } \\
\text { Shallow } \\
\text { Moderate } \\
\text { Deep } \\
\text { Early drain } \\
\text { Late drain } \\
\text { Lowered } \\
\text { Mean }\end{array}$ & $\begin{array}{l}32.2 \\
27.7 \\
25.1 \\
27.2 \\
25.3 \\
24.4 \\
27.1 \text { b }\end{array}$ & $\begin{array}{l}96 \mathrm{~cd} \\
93 \mathrm{fg} \\
92 \mathrm{~g} \\
93 \mathrm{fg} \\
94 \mathrm{ef} \\
93 \mathrm{fg} \\
93.4 \mathrm{~b}\end{array}$ & $\begin{array}{l}80 a b \\
78 a b \\
77 a b \\
77 a b \\
79 a b \\
76 b \\
77.8\end{array}$ & $\begin{array}{l}1.0 \\
1.0 \\
1.0 \\
1.0 \\
1.0 \\
1.0 \\
1.0 \mathrm{~b}\end{array}$ & $\begin{array}{l}21.3 \mathrm{~cd} \\
19.6 \mathrm{~d} \\
19.9 \mathrm{~cd} \\
20.2 \mathrm{cdf} \\
21.6 \mathrm{c} \\
19.6 \mathrm{~d} \\
20.4 \mathrm{~b}\end{array}$ & $\begin{array}{l}8,813 a \\
9,007 a \\
8,835 a \\
9,080 a \\
8,622 a \\
8,543 a \\
8,815 a\end{array}$ \\
\hline $\begin{array}{l}\text { LSD, } 5 \% \\
\text { Herbicide } \\
\text { Water } \\
{ }^{*} \mathrm{H} \times \mathrm{W} \\
\mathrm{CV}, \%\end{array}$ & 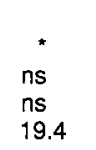 & $\begin{array}{l}* * * \\
* * * \\
1.7 \\
1.9\end{array}$ & $\begin{array}{l}\text { ns } \\
\text { * } \\
3.9 \\
5.2\end{array}$ & $\begin{array}{r}* * * \\
n s \\
n s \\
203\end{array}$ & $\begin{array}{l}* \star \star \star \\
\pi * \star \\
2.0 \\
9.3\end{array}$ & $\begin{array}{c}* \pi \\
1,166 \\
18.7\end{array}$ \\
\hline
\end{tabular}

Means for treatments are not significantly different at $P=5 \%$ if followed by the same letter.
Despite its slower start, ricein deep water produced heads about 4 days before rice in shallow water (table 2). Temperature differences did notexplain this phenomenon, since the deep water was generally cooler than the shallow water. Earlier heading may have been a stress reaction. Grain moisture content at harvest was greater with shallow water, a further indication that water depth affects maturity. Height and lodging were affected by weed competition, but not directly by water treatment.

Grain yield (table 2) was affected by herbicide treatments and water management. The average grain yield for all water treatments without chemicals was half that of the chemically treated plots. There werenoyield differences among water treatments where herbicides were used, but in nonchemical plots, some water treatments did better than others. The highest-yielding nonchemical treatment was deep, which produced $72 \%$ of the yield of the deep treatment with chemicals; the lowest-yielding was shallow, which yielded $23.5 \%$ of the yield of the shallow treatment without chemicals.

Although the 3-year mean yields of chemically treated plots did not differ, yields did differ within individual years. In 1985, shallow and late drain treatments yielded less because low temperatures during and after herbicide application reduced the chemicals' efficacy; in 1986, yields for the deep treatment werelowest because adverse soil conditions (possibly straw residue) affected crop development. From this, we conclude that there is a risk of poor weed
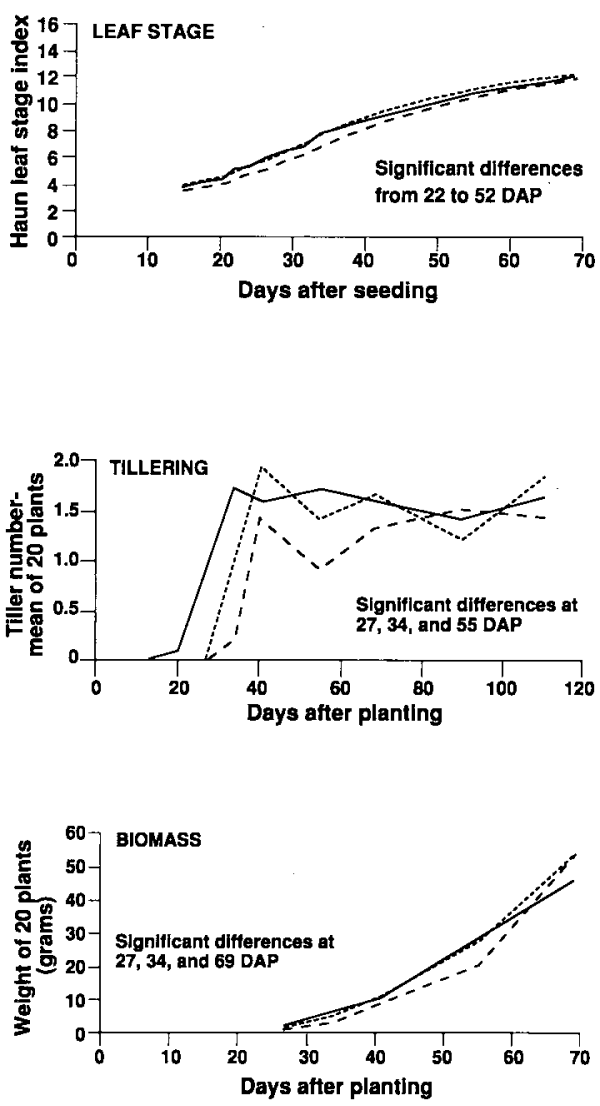

Water treatment:

Shallow _ Moderate -....-.-.. Deep-_-

Fig. 1. Growth patterns of M-201 rice at three water depths. Weeds were chemically controlled. 
TABLE 3. Effect of seeding rate and water depth on yield for six rice cultivars

\begin{tabular}{|c|c|c|c|c|}
\hline & \multicolumn{4}{|c|}{ Seeding rate (Ib/ac) } \\
\hline & 75 & 150 & 225 & Mean \\
\hline $\begin{array}{l}\text { Water depth } \\
\text { Shallow } \\
\text { Moderate } \\
\text { Deep } \\
\text { Mean }\end{array}$ & $\begin{array}{l}9,839 a \\
9,325 \mathrm{c} \\
8,693 d \\
9,286 \mathrm{~b}\end{array}$ & $\begin{array}{l}9,557 a b c \\
9,559 a b c \\
9,378 b c \\
9,496 a b\end{array}$ & $\begin{array}{l}9,757 a b \\
9,839 a \\
9,526 a b c \\
9,702 a\end{array}$ & $\begin{array}{l}9,716 \\
9,537 \\
9,496 \\
9,496\end{array}$ \\
\hline $\begin{array}{l}\text { LSD, } 5 \% \\
\text { Water (W) } \\
\text { Cultivar (C) } \\
\text { Rate (R) } \\
\text { W+C } \\
W+R \\
C+R \\
W+C+R\end{array}$ & $\begin{array}{l}\text { ns } \\
* * * \\
n * * \\
* * * \\
* * * \\
* * * \\
\text { ns }\end{array}$ & & & \\
\hline
\end{tabular}

control if water is too shallow or remains drained for too long a time, and a risk of poor crop performance if water is too deep. The objective of rice water management is to seek a balance between these two risks and thus maintain optimum weed control and maximum yields.

\section{Cultivar performance}

In small, replicated plots in 1986-1987, neither seedling vigor, plant height, lodging, nor yield was affected by water depth across six cultivars hand-sown at $150 \mathrm{lb} / \mathrm{ac}$. Grain moisture at harvest was lower in deep than in shallow water. However, when the same cultivars were evaluated at differentseeding rates at the three water depths, we got somewhat different results (table 3 , main effects only). Increased seeding rates, averaged across six cultivars and three water depths, produced the highest yield at the highest rate. Yield decreased with increasing water depth at the low rate, but was less affected by water depth at seeding rates of 150 or $225 \mathrm{lb} / \mathrm{ac}$.

Long-grain cultivar L-202 was most sensitive to changes in seeding rate and water depth. Its yield increased with higher seeding rates and decreased with deeper water: yields in deep water at a high seeding rate were equal to or higher than in some treatments with lower rates and shallower water. These data suggest that for some cultivars additional seed may partially compensate for the effects of deeper water. Other cultivarstested (S-201,M-201,M-202, M-401, and A-301) were generally less responsive to seeding rate and water depth interactions.

Vigor, biomass production, and height may relate to a cultivar's response to increased water depths and seeding rates. L-202 has the least vigor, height, and vegetative growth of the cultivars tested, and was very responsive. S-201, in contrast, is taller, more vigorous, and more vegetative, but was less responsive to changes in seeding rate and water depth.

\section{Summary and discussion}

Clearly, deep water culture provides substantial control of some (not all) rice weeds, but cannot sustain maximum rice yields in the non-rotated cultural system currently used in California. However, water management is an important complement to a judicious herbicide program, and where conditions limit the efficacy of herbicides, deeper water and a lack of late drainage will improve weed control. Because weedy grasses are more sensitive than rice to water depth, growers will be able to reduce herbicide applications or dispense with them altogether in some situations. Over time, deep water treatments may select for $E$. oryzoides, which is somewhat more tolerant of deep waterand moredifficult tocontrol with herbicides than E. crus-galli. To control weeds like roughseed bulrush that can tolerate deep water, growers will continue to rely on chemical control, crop rotation, and alternative systems. In a nonchemical rice system relying on deep water, roughseed bulrush will eventually become the dominant competitive weed.

While we achieved maximum yields in these trials with 8 inches of water, this depth could cause too much stress in fields with a history of difficulties in stand establishment resulting from such soil-related problems as salinity, alkalinity, and soil texture. We suggest 7 inches as a safer maximum depth that will allow rice to emerge and provide a good yield, but that will adequately suppress sensitiveweeds. Additional seed may help offset the effects of growing rice in deep water, particularly for cultivar L-202. Growers using deeper water must also be vigilant for rice leaf miner, which is less of a problem in shallow water.

Mainstream adoption of these practices may be hindered by the perceived risks and difficulty of managing deep water, and because herbicides are so effective and so easy to use. Organic rice farmers and others who do not use pesticides are more likely to adopt these techniques. However, regulatory pressure and loss of agricultural chemicals should encourage mainstream rice growers touseall available tools to meet the challenge. We hope that rice growers will experiment with these practices at first, and eventually come to view them as useful tools to help them reduce costs, improve weed control, and reduce the chemical residues in their drainwater.

J. F. Williams is Cooperative Extension Farm Advisor, Sutter-Yuba counties; S. R. Roberts is Staff Research Associate, Agronomy and Range Science Extension, UC Davis; J. E. Hill is Agronomist, Agronomy and Range Science Extension, UC Davis; S. C. Scardaci is Cooperative Extension Farm Advisor, Colusa County; and G. Tibbits is a graduate student in Agronomy and Range Science at UC Davis.

The authors would like to thank the Scheidel Farming Company, and particularly Jack and Brett Scheidel, for their support and cooperation in this project.

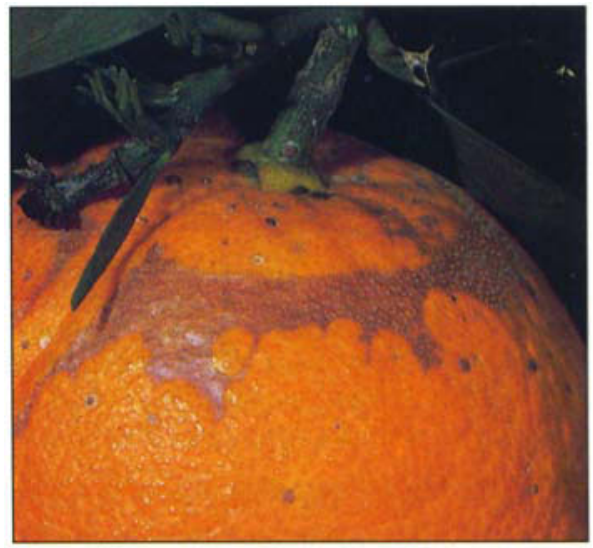

Citrus fruit damaged by thrips develops a characteristic brown ring as it matures.

\section{The McKellar project is a large- scale, multidisciplinary effort in- volving irrigation, nitrogen fertiliza- tion, fungicides, nematicides, miticides, and gibberellin treat- ments. The project, now in its sev- enth and final year, will show which treatments are most efficient and lucrative for growers.}

Arguably the largest and most complex multidisciplinary citrus field experimentever conducted, the McKellar project originated with the Statewide IPM Project. Citrus workers at UC Riverside had been meeting for several years to set research priorities and to rate IPM proposals submitted through the Citrus IPM Workgroup. Since personnel working on citrus were compatible and well organized, the IPM Committee suggested that they undertake a large-scale, multidisciplinary project incorporating most of the practices currently used in citrus production.

\section{Project design}

In 1984 a project was conceived, designed, and submitted to the Statewide IPM Project. The project proposed to maintain trees at three levels of irrigation $(80,100$, or $120 \%$ of evapotranspiration, based on calculated water demand using CIMIS data for evaporation), threelevels of nitrogen(high, $2.7 \%$; medium, 2.5\%; or low, $2.3 \%$ leaf nitrogen), two levels of root health treatments (+ or Ridomil and Vydate to control root-rotting fungi and nematodes), two levels of gibberellin sprays (+ or -, to increase the longevity of fruit), and two levels of miticide ( + or -, to control the citrus red mite).

All treatments were designed to mimic treatments in current use in the citrus industry. For that reason, the project resisted the use of radical treatments sure to produce results, instead incorporating what could be considered normal citrus farming procedures. 